\title{
The effect of simvastatin in pancreas of diabetic rats
}

\author{
Ana Stančić', Aleksandra Korać2, \\ Vesna Otašević1, Aleksandra \\ Janković1, Bato Korać1,2 \\ ${ }^{1}$ University of Belgrade, Institute for \\ Biological Research "Siniša Stanković", \\ Bulevar despota Stefana 142, Belgrade, \\ Serbia; \\ 2 University of Belgrade, Faculty of \\ Biology, Belgrade, Serbia. \\ Address of correspondence: \\ Professor Bato Korać, PhD \\ University of Belgrade, Institute for \\ Biological Research "Siniša Stanković", \\ Department of Physiology \\ Bulevar despota Stefana 142, 11060 \\ Belgrade, Serbia \\ Tel.: (381-11) 2078-307, \\ FAX: (+381 11) 2761-433 \\ e-mail: koracb@ibiss.bg.ac.rs
}

\begin{abstract}
Growing evidences suggest that statins exert several cholesterol-independent pleiotropic effects in diabetes, but there is no consensus whether they are positive or negative. To shed more light on this issue, we examined the effect of simvastatin on $\beta$-cell regeneration in a diabetic state. Diabetes was induced in male Mill Hill rats with a single alloxan dose $(120 \mathrm{mg} / \mathrm{kg})$. Both non-diabetic and diabetic groups were additionally separated into two subgroups: treated with simvastatin $(5 \mathrm{mg} / \mathrm{kg} /$ day, i.g., 12 days) and control. Treatment of diabetic animals started after diabetes induction (glucose level $\geq 12 \mathrm{mmol} / \mathrm{L}$ ). Our findings revealed that there is no increase in the area of insulin-immunopositive cells neither normalization of serum insulin level after simvastatin treatment of diabetic animals, although simvastatin increased nuclear immunopositivity for pancreas duodenum homeobox-1 (PDX-1) and proliferating cell nuclear antigen (PCNA). The data from this study suggest that 12-day treatment with simvastatin did not improve diabetes-induced disturbances in $\beta$-cell mass/function.
\end{abstract}

Key words: Statins, diabetes, insulin, $\beta$-cell regeneration

\section{INTRODUCTION}

Statins represent potent inhibitors of cholesterol biosynthesis, as they inhibit 3-hydroxy-3-methylglutaryl coenzyme A reductase, the rate limiting enzyme in this biosynthetic pathway. Consequently, statins are well established as first-line therapy for decreasing cardiovascular morbidity and mortality in patients with and without coronary disease. Due to its lipid-lowering effects they are also used in the treatment of diabetes-associated hyperlipidemia. However, there are some concerns, coming from the growing experimental and clinical research of statins in diabetes, about the effect of statins on glucose metabolism and glycemic control. Some reports indicate an adverse [1, 2] or no effect of statins on insulin sensitivity $[3,4]$ while others reported a beneficial effect $[5,6]$. Similar discrepancies exist in findings related to the effect of statins on $\beta$-cell mass/function, the second pathological hallmark of the diabetic state. For example, Urbano et al. [7] has found that atorvastatin impairs mitochondrial function in human pancreatic islet and rat $\beta$-cells in vitro. In contrast, recently published in vivo studies showed that statins improved islet function in streptozotocin-induced diabetes and obesity acting through anti-inflammatory and proliferative pathways in $\beta$-cells $[8,9]$. The wide insight into literature data suggests that the effect of statins on glucose metabolism and insulin sensitivity depends on the type, dose and duration of statin treatment as well as the model system (in vitro or in vivo) [10-12].

The special focus in diabetes treatment nowadays is to restore $\beta$-cell population (mass) and consequently their function. The neogenesis of $\beta$-cells from endocrine and exocrine non-insulin producing progenitors gave some promising results in the treatment of experimentally induced diabetes. Several stimuli/conditions have been shown to induce pancreatic potency to regenerate $\beta$-cells, including gastrin and epidermal growth factor, extendin-4, duct ligation etc. [13-16]. Data from our previous study extended this list with L-arginine [17]. Namely, we observed that L-arginine-NO producing pathway induces $\beta$-cell neogenesis in alloxan-induced diabetes acting through the complex transcriptional regulation of $\beta$-cell mass/function.

In the light of such conflicting data regarding statin effects in diabetes, we aimed to examine whether statins affect $\beta$-cell regeneration in diabetic pancreas. Accordingly, the localization/expression of insulin, along with specific insulin-related and proliferative transcription factors including pancreas duodenum homeobox-1 (PDX-1) and proliferating cell nuclear antigen (PCNA), was examined in the pancreas of rats with alloxan-induced diabetes after 12-day treatment with simvastatin. 


\section{MATERIALS AND METHODS}

\section{Animals and diabetes induction}

The experiments were approved by the Ethical Committee for the Treatment of Experimental Animals of the Institute for Biological Research 'Siniša Stanković', Belgrade. Male Mill Hill hybrid hooded, 3-monthold rats (Rattus norvegicus, Berkenhout, 1769) were used. They were divided into two groups: diabetic and non-diabetic rats. Alloxan (Sigma, Germany) was applied to induce diabetes. After a $12 \mathrm{~h}$ fasting period, animals received a single alloxan dose of $120 \mathrm{mg} /(\mathrm{kg}$ body weight) i.p. Rats with blood glucose level $\geq 12$ $\mathrm{mmol} / \mathrm{L}$, measured by glucose oxidase reagent strips (GlucoSure test, "Prizma", Kragujevac, Serbia) were considered diabetic. Both diabetic and non-diabetic groups were additionally separated in two subgroups. One subgroup was treated with simvastatin $(5 \mathrm{mg} / \mathrm{kg} /$ day) through gastric gavage, for 12 days. The second subgroup received intragastric infusion of saline and served as a control. Treatment of diabetic rats started after diabetes induction. The rats were maintained in individual cages with food and water ad libitum. Each experimental group consisted of six animals. After 12 days of treatment, blood glucose level was determined and the rats killed by decapitation. The pancreas was dissected out within 3 min and thoroughly rinsed with physiological saline to remove traces of blood.

\section{Biochemical tests}

Blood was collected, allowed to clot and centrifuged $(3500 \mathrm{~g})$ to prepare serum. Serum insulin levels were estimated by radioimmunoassay (INEP, Belgrade, Serbia). Serum total and HDL (high-density lipoprotein)-cholesterol as well as triglyceride levels were determined by an autoanalyzer (Spectrum CCx, Abbott, Chicago,IL, USA). LDL (low-density lipoprotein)-cholesterol was calculated from measured values of total cholesterol, triglyceride and HDL-cholesterol according to the Friedewald calculation [18].

Student's t test was used to evaluate significance of the differences. Statistical significance was accepted at $\mathrm{P}<0.05$.

\section{Immunohistochemistry}

Immediately after dissection and washing, samples of pancreatic tissue were fixed in 10\% formaldehyde at $4{ }^{\circ} \mathrm{C}$ overnight and processed routinely for embedding in paraffin. $5 \mu \mathrm{m}$-thick serial pancreatic sections were deparaffinized and rehydrated. Immunoreactivity was assessed by the avidin-biotin-peroxidase method (following the manufacturer's instructions; Santa Cruz Biotechnology, Santa Cruz, CA, USA). The sections were incubated with $3 \% \mathrm{H}_{2} \mathrm{O}_{2}$ in methanol for 10 min at ambient temperature to block endogenous peroxidase, followed by three $5 \mathrm{~min}$ washes in $0.015 \mathrm{~mol} / \mathrm{L}$ phosphate-buffered saline (PBS; pH 7.4) and incubated with
$1.5 \%$ normal goat serum (ABC Staining System, Santa Cruz Biotechnology) in PBS for 60 min at ambient temperature to block non-specific sites. Primary antibodies used in this study were anti-PDX-1 (1:1000; Abcam, Cambridge, UK) and anti-PCNA (1:200; Santa Cruz Biotechnology, Santa Cruz, CA, USA). The sections were incubated with the primary antibody in PBS overnight at $4{ }^{\circ} \mathrm{C}$, followed by two 5 min PBS washes, incubated with 1:200 lgG biotinylated serum goat anti-rabbit (ABC Staining System, Santa Cruz Biotechnology) in PBS for $60 \mathrm{~min}$ at ambient temperature, followed by two $5 \mathrm{~min}$ PBS washes. After that, AB reagent ( $A B C$ Staining System, Santa Cruz Biotechnology) was added for 30 min at ambient temperature, followed by three $5 \mathrm{~min}$ PBS washes and incubation with $0.02 \% \mathrm{H}_{2} \mathrm{O}_{2}$ and $0.075 \%$ diaminobenzidine (Sigma) in $0.05 \mathrm{~mol} / \mathrm{L}$ Tris buffer, $\mathrm{pH}$ 7.6, for $10 \mathrm{~min}$ in a dark room. Rinsing in distilled water and counterstaining with hematoxylin completed the experimental schedule.

Insulin and PDX-1 were detected by confocal microscopy. Insulin was detected with anti-insulin antibody (1:1000; Abcam) in combination with fluorescein isothiocyanate (FITC)-conjugated secondary antibody (1:200; Abcam). For PDX-1 staining, the slides were incubated with anti-PDX-1 antibody (1:600; Abcam) followed by incubation with Alexa Fluor 568-labelled secondary antibodies (1:2000; Invitrogen, Paisley, UK). Confocal images were acquired with a Carl Zeiss confocal laser scanning microscope LSM510 and a Windows NT operating system. The examination of fluorescent immunolabelled samples was performed under Ar laser lamp (FITC+Alexa Fluor 568 double-stained samples were excited with $488 \mathrm{~nm}$ and $543 \mathrm{~nm}$ light, respectively).

The specificity of the immune reaction, for both immunofluorescence and routine immunohistochemistry, was tested by replacing the primary antibody with a non-immune rabbit serum or by incubating the sections with the secondary antibody alone.

\section{RESULTS}

\section{Metabolic data}

As it is obvious from Figure 1A, there are no significant differences in blood glucose level in non-diabetic animals, control and simvastatin-treated, between two time points: 1) before treatment (beginning of the experiment) and 2) after 12-days of treatment (end of the experiment). Three time points were represented for glucose level in untreated and simvastatin-treated diabetic animals: 1) before diabetes induction; 2) at the beginning of diabetic state and/or treatment; 3) 12days after diabetes induction and/or treatment with simvastatin (Figure 1B). Level of blood glucose was significantly decreased after 12-days treatment of diabetic animals with simvastatin (point 3) compared to the value detected in those animals before treatment (point 2). 
A)

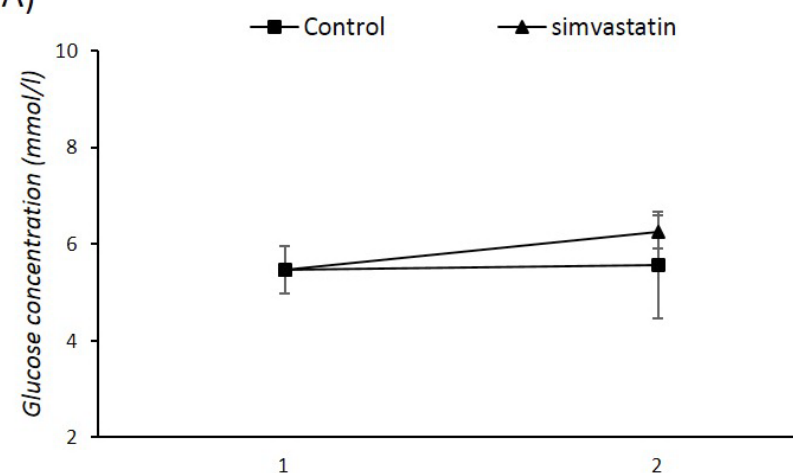

B)

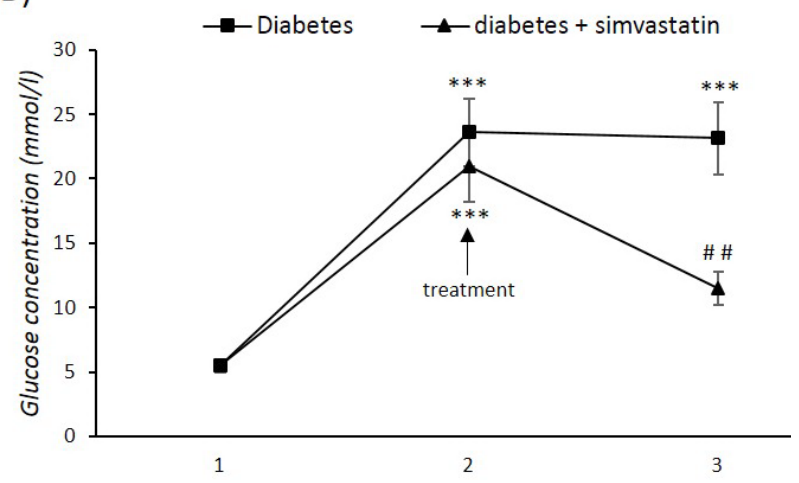

Figure 1. Changes of blood glucose in non-diabetic and diabetic rats. Blood glucose levels in non-diabetic animals, control and simvastatin-treated, are presented for two time points: 1) before treatment (beginning of experiment) and 2) after 12-days of treatment (end of experiment) (A). Glucose levels in untreated and simvastatin-treated diabetic animals are presented for three time points: 1 ) before diabetes induction; 2 ) at the beginning of diabetic state and/or treatment; 3 ) 12-days after diabetes induction and/or treatment with simvastatin (B). The values represent the mean \pm S.E.M of six animals per group. ${ }^{*}$ Compared with value at time point $1,{ }^{* * *} \mathrm{p}<0.001$; \# compared with value at time point 2 , \# \#p $<0.01$.

Figure 2 summarizes the changes of serum insulin, total, HDL-, LDL-cholesterol and triglyceride levels in non-diabetic and diabetic animals. In contrast to the trend for normalization of glucose after simvastatin treatment of diabetic animals, serum insulin level was significantly decreased in those animals compared to control, showing similar value as in untreated diabetes (Figure 2A). Interestingly, total and LDL cholesterol were significantly increased in both simvastatin-treated groups, non-diabetic and diabetic, compared to control (Figure 2B). Furthermore, LDL cholesterol was higher in simvastatin-treated diabetic animals in relation to non-treated diabetic ones. In contrast, diabetic animals treated with simvastatin showed lower triglyceride levels compared to both control and untreated diabetic animals.
A)

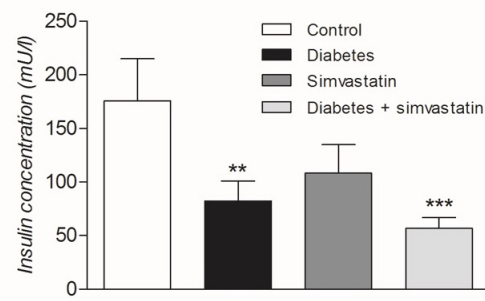

B)

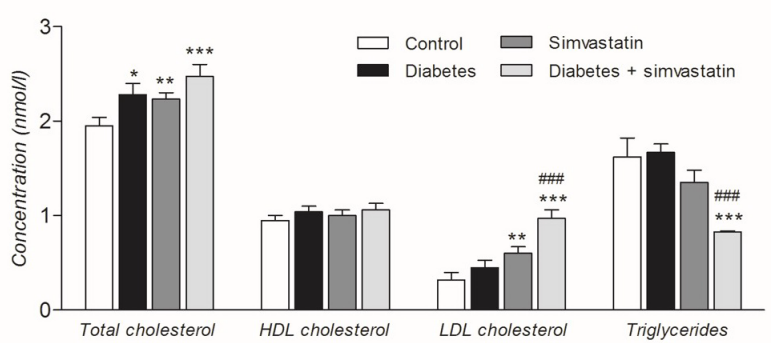

Figure 2. Serum insulin and cholesterols/triglyceride levels in non-diabetic and diabetic rats at the end of experiment ( $A$ and $B$, respectively). Bars represent the mean \pm S.E.M of six animals per group. ${ }^{*}$ Compared to control, ${ }^{*} p<0.05,{ }^{* *} p<0.01$, ${ }^{* * *} \mathrm{p}<0.001$; \# compared to diabetes, \#\# \#p $<0.001$.

\section{Localization/expression of insulin}

As expected, insulin immunopositive areas were significantly decreased in pancreas of diabetic animals (Figure 3B) compared to controls (Figure 3A). Simvastatin treatment of both non-diabetic and diabetic animals did
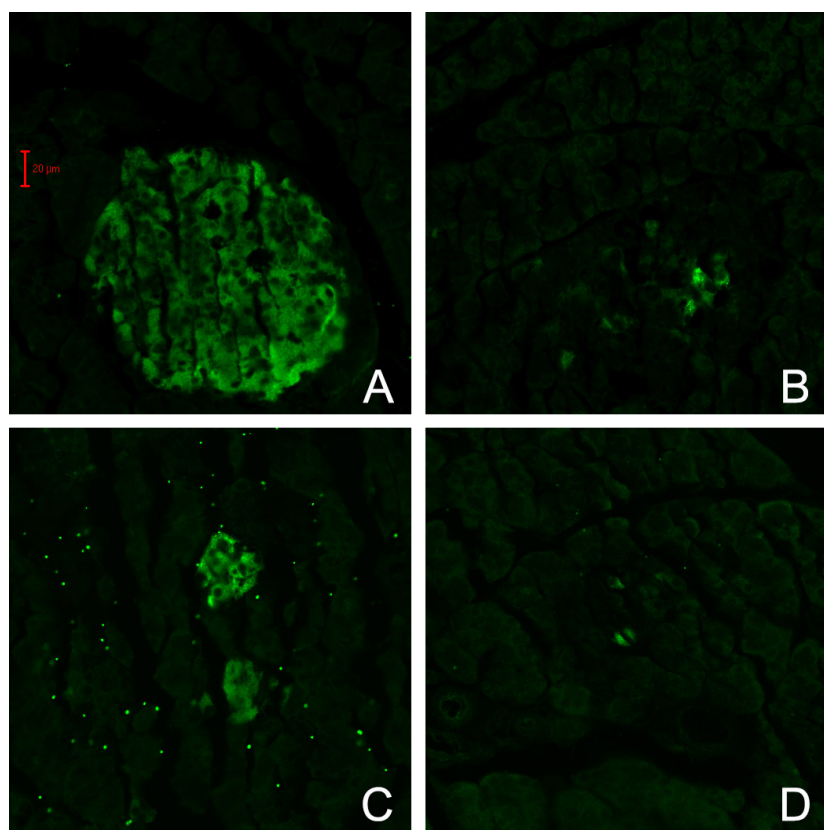

Figure 3. Localization of insulin immunofluorescence in pancreas of control (A), diabetes (B), simvastatin (C) and diabetes + simvastatin (D) animals. Pancreas sections were double-labelled with anti-insulin antibody, and fluorescence analyzed by confocal microscope. Insulin staining appears as green fluorescence. Scale bar, $20 \mu \mathrm{m}$. 
not significantly affect the pattern of insulin immunopositivity observed in the appropriate untreated group (control and diabetic, respectively) but significantly reduced insulin-positive signal in both groups, indicating suppression of insulin synthesis or additional secretion.

\section{Localization/expression of PDX-1 and PCNA}

The results of immunohistochemical staining of PDX-1 are shown on Figure 4. Simvastatin significantly increased the number of immunopositive nuclei as well as cytoplasmic immunopositivity in pancreas of diabetic animals in relation to non-treated diabetic animals. Cytoplasmic immunopositivity is especially strong in tissue of non-diabetic animals treated with simvastatin compared to control.
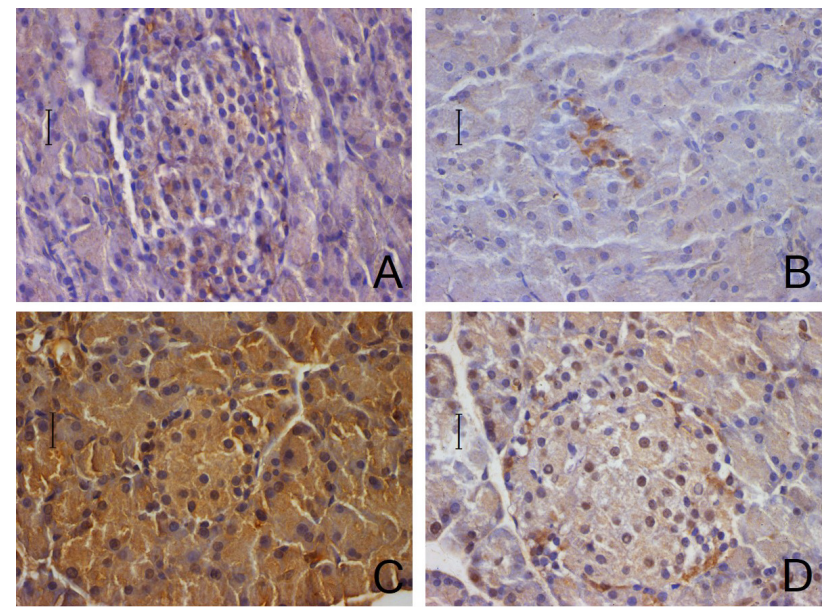

Figure 4. Immunohistochemical staining for PDX-1 in pancreas of control (A), diabetes (B), simvastatin (C), diabetes + simvastatin (D) animals. Numerous nuclei with strong PDX-1 staining can be seen in endocrine and exocrine pancreas of simvastatin-treated diabetic group (D). Scale bars, $20 \mu \mathrm{m}$.
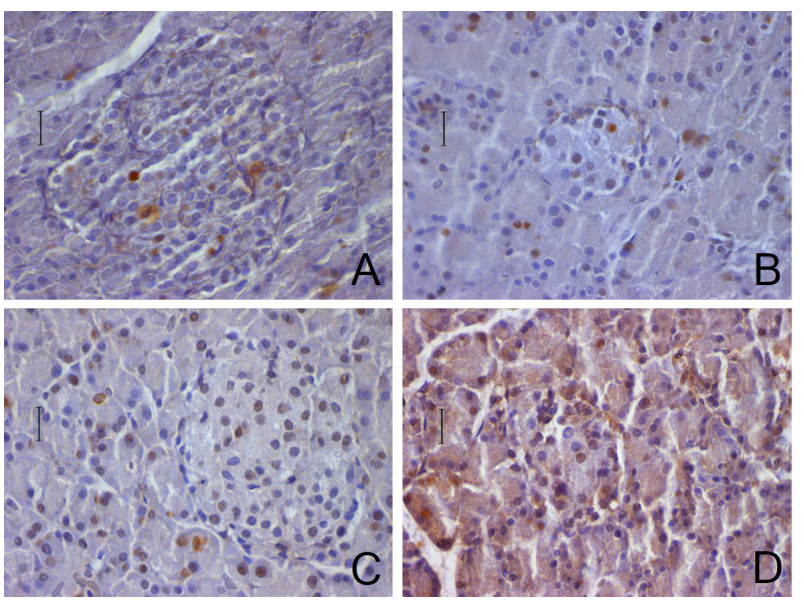

Figure 5. Immunohistochemical staining for PCNA in pancreas of control (A), diabetes (B), simvastatin (C), diabetes + simvastatin (D) animals. Simvastatin treatment induced strong cytoplasmic and nuclear immunopositivity in diabetic pancreas (D). Scale bars, $20 \mu \mathrm{m}$.
Figure 5 shows immunopositivity of PCNA in examined conditions. The number of immunopositive nuclei was increased after simvastatin treatment of both non-diabetic and diabetic animals compared to control and non-treated diabetic animals, respectively. Besides, there was strong immunopositivity in pancreatic cytoplasm of simvastatin-treated diabetic animals.

\section{DISCUSSION}

Growing experimental and clinical research of statins in diabetes clearly suggests cholesterol-independent effects of this drug in this widespread metabolic disease. The results of the present study extended the knowledge on the effect of statins in diabetic pancreatic tissue. We have shown in this study that 12-day treatment with simvastatin did not restore insulin level in the serum and population of insulin-positive $\beta$-cells in the pancreas of diabetic animals. Furthermore, simvastatin treatment of both non-diabetic and diabetic animals, did not significantly affect the pattern of insulin immunopositivity observed in the appropriate untreated group (control and diabetic, respectively), but significantly reduced insulin-positive signal in both groups. The observed results suggest that short-term treatment with statins has no potential to induce $\beta$-cell regeneration.

Wide usage of statins for the treatment of lipid metabolism disturbances of various etiologies opens an important issue about the safety of their use related to glycemic control and glucose metabolism. The main concerns come from clinical studies mainly showing increased risk of development of diabetes type 2 in the subject using statins $[19,20]$. However, data from basic molecular studies are inconsistent. Some of them speak in favor beneficial effects of statins on insulin resistance and $\beta$-cells, other reported negative impact of statin therapy while some showed no effects. In the study presented herein simvastatin reduced insulin-positive signal of both non-diabetic and diabetic animals.

PDX-1 has been described as an important transcription factor that determines endocrine and beta-cell destiny [21-24]. Manipulation of this transcription factor and its signaling pathways has become the dominant approach for $\beta$-cell regeneration and non- $\beta$ to $\beta$-cells reprograming in states where the function of the endocrine pancreas is compromised, including diabetes. We have shown that the L-arginine-NO producing pathway induces activation (nuclear localization) of PDX-1 in the diabetic pancreas [17]. Besides, the increased colocalization of this transcription factor with insulin in endocrine and especially exocrine pancreatic tissue, clearly suggests that L-arginine induces $\beta$-cell regeneration in diabetic pancreas through transdifferentiation of exocrine into endocrine cells.

Comparison of these results with the results of other in vivo studies examining effects of statins on $\beta$-cell 
function establishes the notion that the effect of these drugs will depend on the dose and duration of their application. In the present study simvastatin was administrated in a dose of $5 \mathrm{mg} / \mathrm{kg}$ body weight for 12 days. Li et al. [9] have found increases in islet function and proliferation in streptozotocin-induced diabetes after simvastatin treatment in a dose of $3 \mathrm{mg} / \mathrm{kg} / \mathrm{day}$ but the duration of the treatment was much longer, lasting for 8 weeks. Similar results were found in obese mice treated with atorvastatin with higher dose $(30$ $\mathrm{mg} / \mathrm{kg} /$ day) and longer treatment (58 days) [8].

Interestingly, although there is no increase in $\beta$-cell population after simvastatin treatment, nuclear localization of PDX-1 and PCNA was significantly increased in pancreas of treated animals. The activation of PDX-1 and PCNA in both endocrine and exocrine tissues, has been previously correlated by others $[25,26]$ and ourselves [10] with proliferation and regeneration of pancreatic islet. So, it seems likely that simvastatin administrated in the present schedule (time, dose) recruits the transcriptional program for $\beta$-cell regeneration without achieving the complete process.

Considering the absence of normalization of serum insulin level by simvastatin, we were surprised that this drug counteracted hyperglycemia in diabetic animals. We suggest the possibility that restitution of hyperglycemia by simvastatin results from the peripheral mechanisms operating in regulation of plasma glucose level but not from the direct effect of the drug on the pancreatic tissue. There are growing data from in vitro and in vivo studies speaking in favor our hypothesis. The beneficial effect of statins, including simvastatin [27], on insulin sensitivity have been reported in diabetic patients and animal models of obesity and diabetes. For example, Wong et al. [28] reported that atorvastatin increased glucose uptake in skeletal muscle leading to improved insulin sensitivity in Zucker lean and fatty rats, while Lalli et al. [29] described molecular mechanisms of improved insulin signaling in the liver and skeletal muscle in rats fed a high-fat diet.

However, simvastatin did not normalize total cholesterol level in diabetic rats and even increased LDL cholesterol. Such an unexpected outcome of statin treatment over cholesterol level and inhibition of its synthesis is not an isolated case reported for statin administration in rats. For example, Ness et al. [30] have found that lovastatin increased HMG-CoA reductase activity in rat liver. Furthermore, Isusi et al. [31] have shown that there are differences in the capacity of various types of statins on cholesterol metabolism in liver, while simvastatin has been described as less effective in reduction of cholesterol ester synthesis. Besides, rats have low cholesterol levels that are generally unaffected by statins [32].

According the data from this study we conclude that short-term simvastatin treatment does not improve diabetes-induced decrease in $\beta$-cell mass/function and/or induces $\beta$-cell regeneration. These data are in accordance with growing evidence that question exclusively beneficial effects of statin administration and could be important for defining appropriate clinical use and schedule of statin treatment in non-diabetic and diabetic associated metabolic disturbances.

Acknowledgments: This work was supported by the Ministry of Education, Science and Technological Development of the Republic of Serbia, Grant No. 173055.

\section{REFERENCES}

1. Kostapanos MS, Milionis HJ, Agouridis AD, Rizos CV, Elisaf MS. Rosuvastatin treatment is associated with an increase in insulin resistance in hyperlipidaemic patients with impaired fasting glucose. Int J Clin Pract. 2009; 63(9):1308-13.

2. Moutzouri E, Liberopoulos E, Mikhailidis DP, Kostapanos MS, Kei AA, Milionis $\mathrm{H}$, et al. Comparison of the effects of simvastatin vs. rosuvastatin vs. simvastatin/ezetimibe on parameters of insulin resistance. Int J Clin Pract. 2011; 65(11):1141-8.

3. Gannagé-Yared $M H$, Azar RR, Amm-Azar M, Khalifé $S$, Germanos-Haddad $M$, et al. Pravastatin does not affect insulin sensitivity and adipocytokines levels in healthy nondiabetic patients. Metabolism. 2005 ;54(7):947-51.

4. Yamakawa T, Takano T, Tanaka S, Kadonosono K, Terauchi Y. Influence of pitavastatin on glucose tolerance in patients with type 2 diabetes mellitus. J Atheroscler Thromb. 2008; 15(5):269-75.

5. Sonmez A, Baykal Y, Kilic M, Yilmaz MI, Saglam K, Bulucu $\mathrm{F}$, et al. Fluvastatin improves insulin resistance in nondiabetic dyslipidemic patients. Endocrine. 2003; 22(2):151-4.

6. Meex RC, Phielix E, Schrauwen-Hinderling VB, MoonenKornips E, Schaart G, et al. The use of statins potentiates the insulin-sensitizing effect of exercise training in obese males with and without Type 2 diabetes. Clin Sci (Lond). 2010; 119(7):293-301.

7. Urbano F, Bugliani M, Filippello A, Scamporrino A, Di Mauro S, Di Pino A, et al. Atorvastatin but Not Pravastatin Impairs Mitochondrial Function in Human Pancreatic Islets and Rat $\beta$-Cells. Direct Effect of Oxidative Stress. Sci Rep. 2017; 7(1):11863.

8. Chen ZY, Liu SN, Li CN, Sun SJ, Liu Q, Lei L, et al. Atorvastatin helps preserve pancreatic $\beta$ cell function in obese $\mathrm{C} 57 \mathrm{BL} / 6 \mathrm{~J}$ mice and the effect is related to increased pancreas proliferation and amelioration of endoplasmic-reticulum stress. Lipids Health Dis. 2014; 13:98.

9. Li M, She T, Gan Y, Shao J, Li S, Liao W, et al. Astragaloside IV and statin increased the islet function and proliferation for beta cells in STZ-induced diabetic mice. J Diabetes Metab. 2015; 6(10):611.

10. Otani $M$, Yamamoto $M$, Harada M, Otsuki M. Effect of long- and short-term treatments with pravastatin on diabetes mellitus and pancreatic fibrosis in the Otsuka-Long-Evans-Tokushima fatty rat. Br J Pharmacol. 2010; 159(2):462-73.

11. Baker WL, Talati R, White CM, Coleman Cl. Differing effect of statins on insulin sensitivity in non-diabetics: a system- 
atic review and meta-analysis. Diabetes Res Clin Pract. 2010; 87(1):98-107.

12. Zhao W, Zhao SP. Different effects of statins on induction of diabetes mellitus: an experimental study. Drug Des Devel Ther. 2015; 9:6211-23.

13. Weaver CV, Sorenson RL, Kaung HC. Immunocytochemical localization of insulin-immunoreactive cells in the pancreatic ducts of rats treated with trypsin inhibitor. Diabetologia. 1985; 28(10):781-5.

14. Wang RN, Klöppel G, Bouwens L. Duct- to islet-cell differentiation and islet growth in the pancreas of duct-ligated adult rats. Diabetologia 1995; 38(12):1405-11.

15. Xu G, Stoffers DA, Habener JF, Bonner-Weir S. Exendin-4 stimulates both beta-cell replication and neogenesis, resulting in increased beta-cell mass and improved glucose tolerance in diabetic rats. Diabetes. 1999; 48(12):2270-6.

16. Rooman I, Bouwens L. Combined gastrin and epidermal growth factor treatment induces islet regeneration and restores normoglycemia in C57B/6/J mice treated with alloxan. Diabetologia. 2004; 47(2):259-65.

17. Vasilijevic A, Buzadzic B, Korac A, Petrovic V, Jankovic A, Korac $B$. Beneficial effects of $L$-arginine nitric oxide-producing pathway in rats treated with alloxan. J Physiol. 2007; 584(3):921-33.

18. Friedewald WT, Levy RI, Fredrickson DS. Estimation of the concentration of low-density lipoprotein cholesterol in plasma, without use of the preparative ultracentrifuge. Clin Chem. 1972; 18:499-502.

19. Ridker PM, Pradhan A, MacFadyen JG, Libby P, Glynn RJ. Cardiovascular benefits and diabetes risks of statin therapy in primary prevention: an analysis from the JUPITER trial. Lancet. 2012; 380(9841):565-71.

20. Betteridge DJ, Carmena R. The diabetogenic action of statins - mechanisms and clinical implications. Nat Rev Endocrinol. 2016; 12(2):99-110.

21. Heller RS, Stoffers DA, Bock T, Svenstrup K, Jensen J, Horn T, et al. Improved glucose tolerance and acinar dysmorphogenesis by targeted expression of transcription factor PDX-1 to the exocrine pancreas. Diabetes. 2001; 50(7):1553-61.

22. Kojima H, Nakamura T, Fujita Y, Kishi A, Fujimiya M, Yamada $\mathrm{S}$, et al. Combined expression of pancreatic duodenal homeobox 1 and islet factor 1 induces immature enterocytes to produce insulin. Diabetes. 2002; 51(5):1398-408.
23. Yoshida S, Kajimoto Y, Yasuda T, Watada H, Fujitani Y, Kosaka $H$, et al. PDX-1 induces differentiation of intestinal epithelioid IEC-6 into insulin-producing cells. Diabetes. 2002; 51(8):2505-13.

24. Noguchi H, Kaneto H, Weir GC, Bonner-Weir S. PDX-1 protein containing its own antennapedia-like protein transduction domain can transduce pancreatic duct and islet cells. Diabetes. 2003; 52(7):1732-7.

25. Okamoto H, Akiyama T, Nata K, Ikeda T, Shervani NJ, Kawaguchi S, et al. Reg (Regenerating gene) expression by PARP and NF-kB. Med Sci Monit. 2003; 9:50-60.

26. Lipsett MA, Austin EB, Castellarin ML, Lemay J, Rosenberg $L$,. Evidence for the homeostatic regulation of induced beta cell mass expansion. Diabetologia. 2006; 49(12):2910-19.

27. Paolisso G, Barbagallo M, Petrella G, Ragno E, Barbieri M, Giordano $M$, et al. Effects of simvastatin and atorvastatin administration on insulin resistance and respiratory quotient in aged dyslipidemic non-insulin dependent diabetic patients. Atherosclerosis. 2000; 150(1):121-7.

28. Wong V, Stavar L, Szeto L, Uffelman K, Wang CH, Fantus IG, et al. Atorvastatin induces insulin sensitization in Zucker lean and fatty rats. Atherosclerosis. 2006; 184(2):348-55.

29. Lalli CA, Pauli JR, Prada PO, Cintra DE, Ropelle ER, Velloso LA, et al. Statin modulates insulin signaling and insulin resistance in liver and muscle of rats fed a high-fat diet. Metabolism. 2008; 57(1):57-65.

30. Ness GC, Eales S, Lopez D, Zhao Z. Regulation of 3-hydroxy-3-methylglutaryl coenzyme A reductase gene expression by sterols and nonsterols in rat liver. Arch Biochem Biophys. 1994; 308(2):420-5.

31. Isusi $E$, Aspichueta $P$, Liza $M$, Hernández $M L$, Díaz $C$, Hernández G, et al. Short- and long-term effects of atorvastatin, lovastatin and simvastatin on the cellular metabolism of cholesteryl esters and VLDL secretion in rat hepatocytes. Atherosclerosis. 2000; 153(2):283-94.

32. Tsubouchi H, Inoguchi T, Sonta T, Sato N, Sekiguchi N, Kobayashi K, et al. Statin attenuates high glucose-induced and diabetes-induced oxidative stress in vitro and in vivo evaluated by electron spin resonance measurement. Free Radic Biol Med. 2005; 39(4):444-52. 


\section{Efekat simvastatina u pankreasu dijabetičnih pacova}

\author{
Ana Stančić ${ }^{1}$ Aleksandra Korać2, \\ Vesna Otašević', Aleksandra \\ Janković1, Bato Korać1,2 \\ ${ }^{1}$ Univerzitet u Beogradu, Institut za \\ biološka istraživanja "Siniša Stanković", \\ Bulevar despota Stefana 142, Beograd, \\ Srbija; \\ ${ }^{2}$ Univerzitet u Beogradu, Biološki \\ fakultet, Belgrad, Srbija.
}

\section{Kratak sadržaj}

Sve je više dokaza da statini ostvaruju holesterol-nezavisne efekte u dijabetesu, ali ne postoji saglasnost da li su oni pozitivni ili negativni. U pokušaju da pojasnimo ovaj problem, ispitivali smo efekat simvastatina na regeneraciju $\beta$-ćelija u dijabetesu. Dijabetes je indukovan kod mužjaka Mill Hill pacova jednom dozom aloksana $(120 \mathrm{mg} / \mathrm{kg})$. 1 nedijabetične i dijabetične životinje su podeljene u dve podgrupe: tretirane simvastatinom $(5 \mathrm{mg} / \mathrm{kg} /$ dan, i.g., 12 dana) i kontrolne. Tretman dijabetičnih životinja započelo je nakon indukcije dijabetesa (nivo glukoze $\geq 12 \mathrm{mmol} / \mathrm{L}$ ). Naši rezultati pokazuju da nema povećanja površine insulin-imunopositivnih ćelija niti normalizacije nivoa insulina u serumu nakon tretmana dijabetičnih životinja simvastatinom, iako je simvastatin povećao nukleusnu imunopozitivnost pankreasnog PDX-1 (engl. pancreas duodenum homeobox-1) i PCNA (engl. proliferating cell nuclear antigen). Rezultati studije pokazuju da 12-dnevni tretman simvastatinom nije poboljšao dijabetesom indukovane promene $u$ masi i funkciji $\beta$-ćelija.

Ključne reči: statini, insulin, dijabetes, regeneracija $\beta$-ćelija 